\title{
Serum copper-to-zinc-ratio and risk of incident infection in men: the Kuopio Ischaemic Heart Disease Risk Factor Study
}

\author{
Jaakko T. Laine ${ }^{1} \cdot$ Tomi-Pekka Tuomainen $^{1} \cdot$ Jukka T. Salonen ${ }^{2,3} \cdot$ Jyrki K. Virtanen $^{1}[$
}

Received: 17 June 2019 / Accepted: 5 May 2020 / Published online: 13 May 2020

(c) The Author(s) 2020

\begin{abstract}
Infections are one of the main causes of mortality in elderly due to the decrease of immune response, for which copper $(\mathrm{Cu})$ and zinc $(\mathrm{Zn})$ are claimed to be crucial. High serum copper-to-zinc-ratio $(\mathrm{Cu} / \mathrm{Zn}$-ratio) has been reported with infections, but little is known whether it could also predict the incidence of infections. The study cohort consisted of 1975 men aged 42-60 years and free of severe infectious disease at baseline in 1984-1989 from the prospective population-based Kuopio Ischaemic Heart Disease Risk Factor Study. The main outcome was an incident infection leading to hospitalization. Cox proportional hazards regression models were used for statistical analysis. During the average follow-up of 19.2 years, 636 incident first cases of infections were diagnosed. The hazard ratio (HR) of developing an incident infectious disease in the highest compared to the lowest $\mathrm{Cu} / \mathrm{Zn}$-ratio quartile after adjustment for age and baseline examination year was 1.35 [95\% confidence interval $(\mathrm{CI})=1.07-1.69, P$-trend across quartiles $=0.005]$. The association was slightly attenuated after additional adjustment for potential confounders $(\mathrm{HR}=1.21,95 \% \mathrm{CI}=0.96-1.53, P$-trend $=0.054)$. Furthermore, higher serum $\mathrm{Cu}$ concentration was associated with higher risk of an incident infection. The multivariable-adjusted HR was 1.39 (95\% $\mathrm{CI}=1.10-1.75, P$-trend $=0.005)$ in the highest versus the lowest serum $\mathrm{Cu}$ quartile. Serum $\mathrm{Zn}$ concentration was not associated with the risk (multivariable-adjusted extreme-quartile $\mathrm{HR}=0.83,95 \% \mathrm{CI}=0.67-1.04, P$-trend $=0.218$ ). In conclusion, our data suggest that an increased $\mathrm{Cu} / \mathrm{Zn}$-ratio and especially serum $\mathrm{Cu}$ concentration are associated with increased risk of incident infections in middle-aged and older men in Eastern Finland.
\end{abstract}

Keywords Copper $\cdot$ Zinc $\cdot$ Infections $\cdot$ Population study $\cdot$ Prospective study

\section{Introduction}

Due to the rapidly increasing life expectancy in developed countries, the number of elderly people is rising [1]. Elderly are more susceptible to infections and more often prone to severe complications than the younger individuals [2]. In the population of 65 years and older, infections are responsible

Electronic supplementary material The online version of this article (https://doi.org/10.1007/s10654-020-00644-1) contains supplementary material, which is available to authorized users.

Jyrki K. Virtanen

jyrki.virtanen@uef.fi

1 Institute of Public Health and Clinical Nutrition, University of Eastern Finland, P.O. Box 1627, 70211 Kuopio, Finland

2 Department of Public Health, Faculty of Medicine, University of Helsinki, Helsinki, Finland

3 MAS-Metabolic Analytical Services Oy, Helsinki, Finland not only for one-third of deaths [3] but also for many inpatient stays [4]. One of the major factors for the higher susceptibility to infections is the age-related weakening of the immune system (immunosenescence) [5].

Copper $(\mathrm{Cu})$ and zinc $(\mathrm{Zn})$ are essential micronutrients and crucial components for the development and maintenance of the immune and antioxidative defense system. $\mathrm{Cu}$ and $\mathrm{Zn}$ have an impact especially on the cell-mediated immune reactions of both innate and acquired immune defense [6, 7]. Earlier studies have shown that deficiencies of $\mathrm{Cu}$ and $\mathrm{Zn}$ predispose to infections, but also systemic inflammation and infections induce reduction of serum $\mathrm{Zn}$ concentration during the acute phase response due to the redistribution of the serum $\mathrm{Zn}$ into the liver and other tissues [7]. Furthermore, acute infections lead to an increase of serum $\mathrm{Cu}$ concentration [8]. Both responses result in an increased serum $\mathrm{Cu} / \mathrm{Zn}$-ratio.

Apart from a clear deficiency or supplementation, the serum concentrations of $\mathrm{Zn}$ and $\mathrm{Cu}$ are not significantly 
affected by dietary intakes, but are rather a result of pathophysiological changes in the body $[9,10]$. It has been proposed that serum $\mathrm{Cu} / \mathrm{Zn}$-ratio would be a superior prognostic and predictive marker for several pathological and pre-pathological stages, as it reflects the reciprocal reaction of $\mathrm{Cu}$ and $\mathrm{Zn}$ better than serum $\mathrm{Cu}$ or $\mathrm{Zn}$ concentrations alone [9]. High serum $\mathrm{Cu} / \mathrm{Zn}$-ratio is claimed to be associated with higher risk of cardiovascular mortality [11, 12], different cancers [13, 14], and all-cause mortality [15]. A higher plasma $\mathrm{Cu} / \mathrm{Zn}$-ratio was discovered among hospitalized people aged 70 or older than in their healthy controls [16]. Furthermore, it was found that $\mathrm{Cu} / \mathrm{Zn}$-ratio significantly increases with aging, as $\mathrm{Zn}$ concentration decreases and $\mathrm{Cu}$ concentration increases with advancing age [17]. A mild $\mathrm{Zn}$ deficiency has been claimed to be quite prevalent in the elderly population even in developed countries [5, 18]. Similarly, decreased serum Zn concentration and increased $\mathrm{Cu} / \mathrm{Zn}$-ratio has been observed due to a chronic exposure to cadmium especially in smokers [19].

Furthermore, little is known whether the serum $\mathrm{Cu} / \mathrm{Zn}$ ratio could have an impact on the risk of getting an infection. Therefore, we investigated the relation of serum $\mathrm{Cu} / \mathrm{Zn}$-ratio with the risk of incident infections in a long-term prospective cohort study in middle-aged and older Finnish men.

\section{Materials and methods}

\section{Study population}

The Kuopio ischaemic heart disease risk factor (KIHD) Study was designed to investigate risk factors for cardiovascular disease, atherosclerosis, and related outcomes in a population-based sample of men from eastern Finland [20]. The baseline examinations were carried out in 1984-1989. A total of 2682 men who were $42,48,54$, or 60 years old at baseline ( $83 \%$ of those eligible) were recruited in 2 cohorts. The first cohort consisted of 1166 men who were 54 years old and enrolled in 1984-1986, and the second cohort included 1516 men who were $42,48,54$, or 60 years old and enrolled in 1986-1989. The baseline characteristics of the entire study population were described previously [20].

Data on serum $\mathrm{Cu}$ and $\mathrm{Zn}$ were available for 2573 men. Participants who had the serum CRP $>10 \mathrm{mg} / \mathrm{L}(\mathrm{n}=68)$, or those with a diagnosis of chronic diseases that are associated with increased risk of infections, such as chronic bronchitis $(n=195)$, lung tuberculosis $(n=87)$, bronchial asthma $(n=61)$, liver or pancreas disease $(n=30)$ or kidney stones $(n=122)$, chronic prostatitis $(n=2)$, thyroid therapy $(n=17)$, or rheumatoid arthritis $(n=16)$ at entry, were excluded, leaving 1975 men for the analysis. In the sensitivity analyses, we further excluded men with potentially increased risk of infections, including men with history of ischaemic heart disease, stroke, cancer or diabetes $(n=551)$, leaving 1424 men for these analyses.

\section{Data collection}

Fasting venous blood samples were drawn between 08.00 and 10.00 at baseline. Subjects were instructed to abstain from ingesting alcohol for 3 days and from smoking and eating for $12 \mathrm{~h}$ before providing the sample. Copper-free needles and tubes were used for collecting and storing the blood samples. The subjects rested in a supine position for $30 \mathrm{~min}$ before blood sampling. A tourniquet was not used.

Detailed descriptions of the assessment of medical history and medications [21], family history of diseases [21], smoking [21], alcohol consumption [21], serum ferritin [21], and physical activity [22], at baseline have been published. Education and annual income were obtained from a self-administered questionnaire. BMI was computed as the ratio of weight in kilograms to the square of height in meters. Dietary intakes at baseline were assessed with 4-day food records [23]. Serum $\mathrm{Cu}$ and $\mathrm{Zn}$ concentrations were determined by atomic absorption spectrometry from frozen samples stored at $-20{ }^{\circ} \mathrm{C}$ for $1-5$ years prior to analyses. Serum zinc concentrations were determined in the same batches with copper, method for which has been described before [24]. The PerkinElmer 306 atomic absorption spectrophotometer (Norwalk, Connecticut, USA) was used for measurements (Seronorm Nycomed, Oslo, Norway). Control serum samples were included in all daily batches. The reference standards were dissolved in 5\% glycerol. The between-batch coefficient of variation was $4.0 \%$. An immunometric assay (Immulite High Sensitivity C-reactive Protein Assay; DPC, Los Angeles, USA) was used to measure serum high-sensitivity CRP.

\section{Ascertainment of follow-up events}

Follow-up diagnoses until 31 December 2012 were collected by record linkage to the national hospital discharge register using the Finnish personal identification code. International Classification of Diseases (ICD)- 8 codes 002, 003, 008, 009, 035, 038, 053, 057, 060, 070, 078, 079, 380, 381, 420, 421, 460, 461, 465, 466, 472, 473, $480,482,485,486,590,595,601,604,680-682$ and ICD10 codes A04, A07-A09, A32, A40, A41, A46, A49, A69, A98, B00, B02, B24, B25, B34, B99, G03, H60, I33, I40, J01, J06, J13, J15, J18, J20-J22, L02, L03, L30, M00, $\mathrm{M} 01, \mathrm{~N} 10, \mathrm{~N} 30, \mathrm{~N} 39, \mathrm{~N} 41$ and $\mathrm{N} 45$ were used to indicate an infection. Only the first incident event diagnosis was counted. 


\section{Statistical analysis}

The distributions of the baseline characteristics in quartiles of serum $\mathrm{Cu} / \mathrm{Zn}$-ratio were presented as means [ \pm standard deviations (SD)] or percentages. The associations between serum $\mathrm{Cu} / \mathrm{Zn}$-ratio and baseline characteristics were analysed by using Chi square tests (for categorical variables) and by linear regression (for continuous variables).

Multivariable-adjusted Cox proportional hazards regression models were used to estimate the hazard ratios in quartiles of baseline serum $\mathrm{Cu} / \mathrm{Zn}$-ratio and in quartiles of $\mathrm{Cu}$ and $\mathrm{Zn}$ concentrations. Participants contributed follow-up time until the first diagnosis of incident infectious disease, death or the end of follow-up, which ever came first. The confounders were selected on the basis of risk factors for infections. Model 1 included age (years) and baseline examination year. Model 2 included model 1 plus history of ischemic heart disease, stroke, cancer or diabetes (yes/ no); smoking (never smoker, previous smoker, current smoker $<20$ cigarettes/day, current smoker $\geq 20$ cigarettes/ day); education (years); income (euros/year); intake of alcohol (g/week); leisure-time physical activity (kcal/day); and BMI $\left(\mathrm{kg} / \mathrm{m}^{2}\right)$. The cohort mean was used to replace missing values $(<2.3 \%)$. Potential nonlinear associations were assessed semiparametrically using restricted cubic splines. Statistical significance of the interactions with serum albumin and BMI medians and with smoking status (current smokers vs. others) on a multiplicative scale was assessed by likelihood ratio tests using a cross-product term with $\mathrm{Cu} / \mathrm{Zn}$-ratio and $\mathrm{Cu}$ and $\mathrm{Zn}$ concentrations as continuous variables. Similar analyses were conducted by stratifying the analyses with serum $\mathrm{Cu}$ concentration by the median of serum $\mathrm{Zn}$ concentration and vice versa. Statistical analyses were performed using SPSS software version 25 for Macintosh (Armonk, NY, IBM Corp.) and Stata 14.1 (Stata Corp., College Station, TX; for spline analysis). All $P$-values were two-sided.

\section{Results}

The mean age of the 1975 men was 52.8 years and the mean serum $\mathrm{Cu} / \mathrm{Zn}$-ratio was 1.2 (SD 0.2, range 0.6-3.0). The mean serum $\mathrm{Cu}$ and $\mathrm{Zn}$ concentrations were $17.4 \mu \mathrm{mol} / \mathrm{L}$ (SD $2.7 \mu \mathrm{mol} / \mathrm{L}$, range $7.2-36.5 \mu \mathrm{mol} / \mathrm{L}$ ) and $14.4 \mu \mathrm{mol} / \mathrm{L}$ (SD $1.8 \mu \mathrm{mol} / \mathrm{L}$, range $8.3-24.8 \mu \mathrm{mol} / \mathrm{L}$ ), respectively. The baseline characteristics of the cohort members according to the quartiles of serum $\mathrm{Cu} / \mathrm{Zn}$-ratio are shown in Table 1 . Men with a higher serum $\mathrm{Cu} / \mathrm{Zn}$-ratio were more likely to be older, be current smokers, consume more alcohol, be less educated and have a lower income than men with a lower serum $\mathrm{Cu} / \mathrm{Zn}$-ratio. Additionally, men with a higher $\mathrm{Cu} / \mathrm{Zn}$ ratio were more likely to have a higher serum $\mathrm{C}$-reactive protein concentration and a lower serum albumin concentration. Among dietary factors, men with a higher serum $\mathrm{Cu} / \mathrm{Zn}$-ratio had higher intake of fish and butter and lower intakes of vegetable margarines and oils, grains and fruits, berries, vegetables and roots. There was no appreciable difference in $\mathrm{Zn}$ intake between the groups. We did not have information on $\mathrm{Cu}$ intake.

During the average follow-up time of 19.2 years (SD: 8.0 years; minimum-maximum $0.1-28.7$ years), 636 first infections requiring hospitalization occurred. Of these, 171 (26.9\%) were pneumonia, $81(12.7 \%)$ were erysipelas and $34(5.3 \%)$ were acute bronchitis. After adjustment for age and baseline examination year, those in the highest versus the lowest $\mathrm{Cu} / \mathrm{Zn}$-ratio had 35\% higher risk of an incident infection $(95 \% \mathrm{CI}=7-69 \%$; $P$-trend across quartiles 0.005$)$ (Table 2, model 1). The association was attenuated after further multivariate adjustments for potential confounders but the trend towards higher risk remained borderline statistically significant $(P$-trend $=0.054)$ (Table 2 , model 2$)$. There was no evidence for non-linearity (Fig. 1). Further adjustment for serum albumin as a potential marker for poor nutritional status had no impact on the associations (data not shown).

In the analysis with serum $\mathrm{Cu}$ and $\mathrm{Zn}$ concentrations separately, higher serum $\mathrm{Cu}$ concentration was associated with higher risk of an incident infection. In the multivariable-adjusted model (Table 2, model 2), those in the highest versus the lowest serum $\mathrm{Cu}$ quartile had 39\% higher risk of an incident infection (95\% CI $=10-75 \% ; P$-trend $=0.005)$, without evidence for non-linearity (Fig. 1). No statistically significant associations were observed with serum $\mathrm{Zn}$ concentration (Table 2, Fig. 1).

In the sensitivity analysis, we evaluated the associations of $\mathrm{Cu} / \mathrm{Zn}$-ratio and serum $\mathrm{Cu}$ and $\mathrm{Zn}$ concentrations with the incidence of an infection during the first 10 years of follow-up, because the associations with a single measurement at baseline may be attenuated with a long follow-up period. After adjustment for potential confounders (Model 2), men in the highest versus the lowest $\mathrm{Cu} / \mathrm{Zn}$-ratio had $43 \%$ higher risk of an incident infection (202 events) (95\% CI $=0.95-116 \%$; $P$-trend $=0.043$ ) (Supplementary table). Those in the highest versus the lowest serum $\mathrm{Cu}$ quartile had 50\% higher risk (95\% $\mathrm{CI}=0.98-130 \% ; P$-trend $=0.062)$ (Model 2, Supplementary table). In these analyses also serum $\mathrm{Zn}$ concentration was associated with the risk of an incident infection, with 35\% lower risk in the highest compared to the lowest quartile (95\% $\mathrm{CI}=4-55 \%)$. However, although the $P$ value for trend across the quartiles was statistically significant $(P$-trend $=0.035)$, the lower risk was observed already in the second quartile and the risk did not decrease further with increasing serum $\mathrm{Zn}$ concentration (Supplementary table). Because the serum concentrations of both $\mathrm{Cu}$ and $\mathrm{Zn}$ are affected by the acute phase response, we also analysed the associations after excluding the 
Table 1 Baseline characteristics of 1975 KIHD participants by quartiles of serum Cu/Zn-ratio

\begin{tabular}{|c|c|c|c|c|c|}
\hline \multirow[t]{2}{*}{ Characteristic } & \multicolumn{4}{|c|}{ Serum $\mathrm{Cu} / \mathrm{Zn}$-ratio quartile } & \multirow[t]{2}{*}{$P$-trend ${ }^{\mathrm{a}}$} \\
\hline & $1(0.59-1.03)$ & $2(1.04-1.17)$ & $3(1.18-1.33)$ & $4(1.34-2.97)$ & \\
\hline Participants, $n$ & 494 & 493 & 495 & 493 & \\
\hline Age, years & $52.0(5.5)^{\mathrm{b}}$ & $52.6(5.2)$ & $52.8(5.1)$ & $53.7(5.0)$ & $<0.001$ \\
\hline Body mass index, $\mathrm{kg} / \mathrm{m}^{2}$ & $26.7(3.3)$ & $27.0(3.7)$ & $26.8(3.4)$ & $26.8(3.7)$ & 0.990 \\
\hline Leisure time physical activity, kcal/day & $135(151)$ & 155 (177) & $139(171)$ & $128(170)$ & 0.235 \\
\hline Education, years & $9.4(4.0)$ & $8.7(3.5)$ & $8.6(3.3)$ & $8.2(3.1)$ & $<0.001$ \\
\hline Income, Euros/year & 14745 (9937) & $13933(9514)$ & $13427(7910)$ & $12300(9004)$ & $<0.001$ \\
\hline Alcohol intake, g/week & $56(103)$ & $57(86)$ & $72(107)$ & $108(157)$ & $<0.001$ \\
\hline Current smoker, $\%$ & 21 & 24 & 30 & 41 & $<0.001$ \\
\hline Multivitamin use, $\%$ & 2.0 & 1.0 & 0.2 & 1.0 & 0.049 \\
\hline $\begin{array}{l}\text { History of ischemic heart disease, stroke, } \\
\text { cancer or diabetes, } \%\end{array}$ & 24 & 28 & 28 & 33 & 0.003 \\
\hline Serum C-reactive protein, $\mathrm{mg} / \mathrm{L}$ & $1.2(1.1)$ & $1.5(1.4)$ & $1.8(1.6)$ & $2.7(2.3)$ & $<0.001$ \\
\hline Serum ferritin, nmol/L & $0.4(0.3)$ & $0.4(0.3)$ & $0.4(0.4)$ & $0.4(0.3)$ & 0.242 \\
\hline Serum albumin, $\mathrm{g} / \mathrm{L}$ & $43.2(3.4)$ & $42.8(3.5)$ & $42.1(3.6)$ & $41.6(3.5)$ & $<0.001$ \\
\hline \multicolumn{6}{|l|}{ Dietary intakes } \\
\hline Energy intake, kcal/day & $2455(588)$ & $2486(585)$ & $2423(620)$ & $2405(656)$ & 0.083 \\
\hline Meat $\mathrm{g} / \mathrm{d}^{\mathrm{c}}$ & $160(88)$ & $158(76)$ & $157(80)$ & $161(76)$ & 0.916 \\
\hline Dairy g/d & $709(362)$ & $723(350)$ & $711(361)$ & $702(367)$ & 0.660 \\
\hline Fish g/d & $40(48)$ & $44(52)$ & $46(51)$ & $52(59)$ & $<0.001$ \\
\hline Eggs, g/d & $34(26)$ & $33(26)$ & $32(24)$ & $31(26)$ & 0.074 \\
\hline Grains, g/d & $262(93)$ & $266(93)$ & $252(92)$ & $241(95)$ & $<0.001$ \\
\hline Vegetable margarines and oils, g/d & $22(18)$ & $20(17)$ & $19(16)$ & $17(15)$ & $<0.001$ \\
\hline Butter, g/d & $29(25)$ & $34(27)$ & $32(25)$ & $36(29)$ & 0.002 \\
\hline Fruits, berries, vegetables, roots, g/d & $437(175)$ & $433(174)$ & $418(193)$ & $386(165)$ & $<0.001$ \\
\hline Zinc, $\mathrm{mg} / \mathrm{d}^{\mathrm{d}}$ & $15(4)$ & $15(3)$ & $15(3)$ & $15(3)$ & 0.302 \\
\hline
\end{tabular}

${ }^{a} P$-trend was calculated by using linear regression (continuous variables) or by Chi square test (categorical variables)

${ }^{b}$ Values are means (SD) or percentages

${ }^{\mathrm{c}}$ Includes red meat, white meat, game and offal

${ }^{\mathrm{d}}$ Values adjusted for total energy intake using the residual method

infections that occurred during the first two years of follow-up $(\mathrm{n}=37)$. This had only little impact on the associations: the HR $(95 \%$ CI) in the highest versus the lowest quartile was $1.16(0.94-1.50, P$-trend $=0.06)$ for the $\mathrm{Cu} / \mathrm{Zn}$-ratio, 1.40 $(1.10-1.78, P$-trend $=0.005)$ for $\mathrm{Cu}$ and $0.89(0.71-1.11$, $P$-trend $=0.47$ ) for $\mathrm{Zn}$. If the analyses were restricted to the men without history of ischemic heart disease, stroke, cancer or diabetes ( $n=1424,434$ incident infections), the association with $\mathrm{Cu} / \mathrm{Zn}$-ratio was attenuated (Model 2, extreme-quartile $\mathrm{HR}=1.22,95 \% \mathrm{CI}=0.91-1.63 ; P$-trend $=0.24)$, but the association with $\mathrm{Cu}$ was stronger (extreme-quartile $\mathrm{HR}=1.50,95 \%$ $\mathrm{CI}=1.14-1.99 ; P$-trend $=0.01)$. There was no statistically significant association between serum $\mathrm{Zn}$ and incident infections in these analyses, either (extreme-quartile $\mathrm{HR}=0.88,95 \%$ $\mathrm{CI}=0.67-1.16 ; P$-trend $=0.57$ ). Finally, we evaluated whether serum albumin concentration, BMI or smoking would modify the associations. The only statistically significant interaction was observed between BMI and serum Zn concentration.
Serum Zn concentration was associated with a lower risk among men with BMI above the median (BMI $>26.4 \mathrm{~kg} / \mathrm{m}^{2}$, Model 2 extreme-quartile $\mathrm{HR}=0.70,95 \% \mathrm{CI}=0.52-0.94$; $P$-trend $=0.08)$, but no association was observed among the men with BMI below the median (extreme-quartile $\mathrm{HR}=1.03$, 95\% CI 0.73-1.45; $P$-trend $=0.92)(P$-interaction $=0.049)$. All other interactions were statistically non-significant $(P$-interactions $>0.15)$. Neither did we find evidence that the association of serum $\mathrm{Cu}$ with risk of an incident infection would be modified by serum $\mathrm{Zn}$ concentrations $(P$-interaction $=0.33)$ or vice versa $(P$-interaction $=0.49)$.

\section{Discussion}

In this prospective, population-based cohort study, we found that a higher $\mathrm{Cu} / \mathrm{Zn}$-ratio and a higher concentration of serum $\mathrm{Cu}$ were associated with a higher risk of an 
Table 2 Risk of an incident infection according to the quartiles of serum $\mathrm{Cu} / \mathrm{Zn}$-ratio and $\mathrm{Cu}$ and $\mathrm{Zn}$ concentration

\begin{tabular}{llllll}
\hline Serum parameter & \multicolumn{2}{l}{ Quartile of serum parameter } & & \multirow{2}{*}{$P$-trend } \\
\cline { 2 - 5 } & 1 & 2 & 3 & 4 & \\
\hline Serum Cu/Zn-ratio & $0.59-1.03$ & $1.04-1.17$ & $1.18-1.33$ & $1.34-2.97$ & \\
N of events/subjects & $140 / 494(28.3 \%)$ & $157 / 493(31.8 \%)$ & $174 / 495(35.2 \%)$ & $165 / 493(33.5 \%)$ & \\
IR/1000 PY & 13.8 & 16.0 & 18.4 & 19.0 & 0.005 \\
Model 1 & 1 & $1.14(0.91-1.43)^{\mathrm{a}}$ & $1.33(1.06-1.66)$ & $1.35(1.07-1.69)$ & 0.054 \\
Model 2 & 1 & $1.08(0.86-1.36)$ & $1.28(1.02-1.60)$ & $1.21(0.96-1.53)$ & \\
Serum Cu ( $\mu$ mol/L) & $7.24-15.58$ & $15.59-17.31$ & $17.32-18.88$ & $18.89-36.51$ & \\
N of events/subjects & $124 / 453(27.4 \%)$ & $182 / 573(31.8 \%)$ & $156 / 475(32.8 \%)$ & $174 / 474(36.7 \%)$ & \\
IR/1000 PY & 13.2 & 15.9 & 17.6 & 20.7 & \\
Model 1 & 1 & $1.17(0.93-1.48)$ & $1.30(1.03-1.65)$ & $1.60(1.27-2.02)$ & $<0.001$ \\
Model 2 & 1 & $1.13(0.90-1.43)$ & $1.20(0.94-1.52)$ & $1.39(1.10-1.75)$ & 0.005 \\
Serum Zn ( $\mu$ mol/L) & $8.26-13.15$ & $13.16-14.22$ & $14.23-15.30$ & $15.31-24.78$ & \\
N of events/subjects & $177 / 493(35.9 \%)$ & $141 / 499(28.3 \%)$ & $161 / 493(32.7 \%)$ & $157 / 490(32.0 \%)$ & \\
IR/1000 PY & 20.2 & 14.4 & 16.3 & 16.2 & 0.307 \\
Model 1 & 1 & $0.68(0.54-0.85)$ & $0.80(0.65-1.00)$ & $0.85(0.69-1.06)$ & 0.218 \\
Model 2 & 1 & $0.71(0.57-0.89)$ & $0.84(0.67-1.04)$ & $0.83(0.67-1.04)$ & 0.218 \\
\hline
\end{tabular}

${ }^{a}$ Values are hazard ratio (95\% confidence interval)

$I R$ incidence rate, $P Y$ person-years

Model 1: adjusted for age and examination year

Model 2: adjusted for model 1 and history of coronary heart disease, stroke, cancer or diabetes (yes/no); smoking (never smoker, previous smoker, current smoker $<20$ cigarettes/day, current smoker $\geq 20$ cigarettes/day); education (years); income (euros/year); intake of alcohol (g/week); leisure-time physical activity (kcal/day); and body mass index incident infection requiring hospitalization, in middle-aged and older men from Eastern Finland. Serum Zn concentration was associated with the risk only in the analysis with a shorter follow-up of 10 years but not in the analyses with the full follow-up of an average 19 years. To our knowledge, the present study is the first to report on the relation between $\mathrm{Cu} / \mathrm{Zn}$-ratio and infection incidence in a population-based setting.

The observation of the higher risk with higher $\mathrm{Cu} / \mathrm{Zn}$ ratio may have various reasons. For the proper functioning of the innate and adapted immune response both of these micronutrients and their reciprocal relation are essential [25]. The optimum of the serum $\mathrm{Cu} / \mathrm{Zn}$-ratio lies between 0.7 and 1.0 [25], and also in our study the risk started to increase after the ratio exceeded 1.0 (Fig. 1). An increased serum $\mathrm{Cu} / \mathrm{Zn}$-ratio has been suggested as a valuable clinical marker in several case-control studies with bacterial, viral and parasitic infections [26-28], and in cohort studies with risk of all-cause, cancer, cardiovascular or HIV-1 mortality [11, 12, 15, 29]. Elderly are more susceptible to infections than younger people, and infections are an important cause not only for morbidity and mortality but also for hospital-admissions in elderly individuals [30]. Partly, this is due to the age-related weakening of the immune system (immunosenescence) [31]. Both $\mathrm{Cu}$ and $\mathrm{Zn}$ participate in antioxidant stress modulation $[32,33]$, and $\mathrm{Cu} / \mathrm{Zn}$-ratio had been used as a marker of oxidative stress burden [34]. A higher $\mathrm{Cu} / \mathrm{Zn}$-ratio may thus reflect an elevated oxidative stress burden, which may boost the age-related weakening of the immune system and contribute to the susceptibility to infections during ageing. Furthermore, it has been suggested that the increase of the serum $\mathrm{Cu} / \mathrm{Zn}$-ratio seems to be a frequent phenomenon related to age, chronic diseases and their pathological changes [9].

It has been suggested that the serum $\mathrm{Cu} / \mathrm{Zn}$-ratio is a superior marker of events to either serum $\mathrm{Cu}$ or $\mathrm{Zn}$ concentration separately [35]. However, in the present study serum $\mathrm{Cu}$ concentration had a stronger association with incidence of an infection than the serum $\mathrm{Cu} / \mathrm{Zn}$-ratio. The mean $\mathrm{Cu}$ concentration of the subjects in this study (17.4 $\mu \mathrm{mol} / \mathrm{L}$ ) corresponds well to the mean $\mathrm{Cu}$ concentrations for men obtained in studies in several European countries [36]. Of the subjects, $4.5 \%$ have higher $\mathrm{Cu}$ concentration than the upper reference value of $\mathrm{Cu}(22.0 \mu \mathrm{mol} / \mathrm{L})$. The concentration of serum $\mathrm{Cu}$ is typically elevated in inflammation and infections [8], but the specific reasons for this phenomenon are still not clarified in detail [29]. The high concentration of serum $\mathrm{Cu}$ corresponds to the elevation of ceruloplasmin in serum. Ceruloplasmin is elevated in acute phase response [37]. As ceruloplasmin plays an important role in iron metabolism, it has been proposed that the high serum concentration of ceruloplasmin could rather reflect 

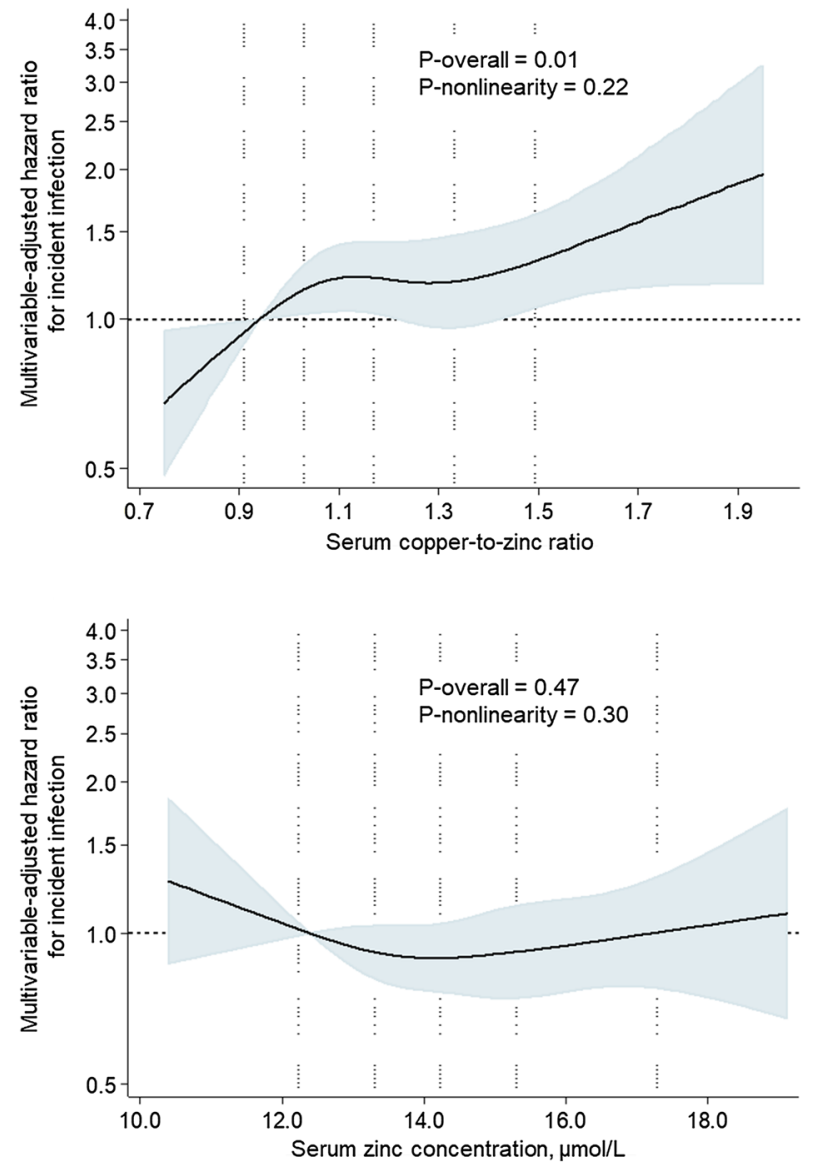

Fig. 1 Hazard ratios of the serum copper-to-zinc-ratio and serum copper and serum zinc with risk of an incident infection among 1975 men, evaluated by restricted cubic splines from Cox proportional hazards models. The model is adjusted for age (years), examination year, history of coronary heart disease, stroke, cancer or diabetes (yes/ no); smoking (never smoker, previous smoker, current smoker $<20$ cigarettes/day, current smoker $>20$ cigarettes/day); education (years);

its role in iron mobilization and homeostasis and be the consequence of iron sequestration from microbes [38]. One potential explanation for the association between serum $\mathrm{Cu}$ concentration and infection incidence could thus be reverse causality. However, this may not be a likely explanation, because excluding the incident infections that occurred during the first 2 years of follow-up did not affect the associations with $\mathrm{Cu}$.

The serum $\mathrm{Zn}$ concentration is typically decreased in infections [39]. This may be due to Zn deficiency [6], defined as a serum $\mathrm{Zn}$ concentration below $10.7 \mu \mathrm{mol} / \mathrm{L}$ [40], or due to the nutritional immunity [41], as serum $\mathrm{Zn}$ is redistributed through activation of inflammatory cytokines in particular into the liver [7, 42]. Furthermore, a decrease of serum $\mathrm{Zn}$ concentration and consequently an increase of $\mathrm{Cu} / \mathrm{Zn}$-ratio have been observed with advancing age [17]. It has been claimed that free-living elderly are prone to mild Zn deficiency $[5,18]$. This may be linked to several factors

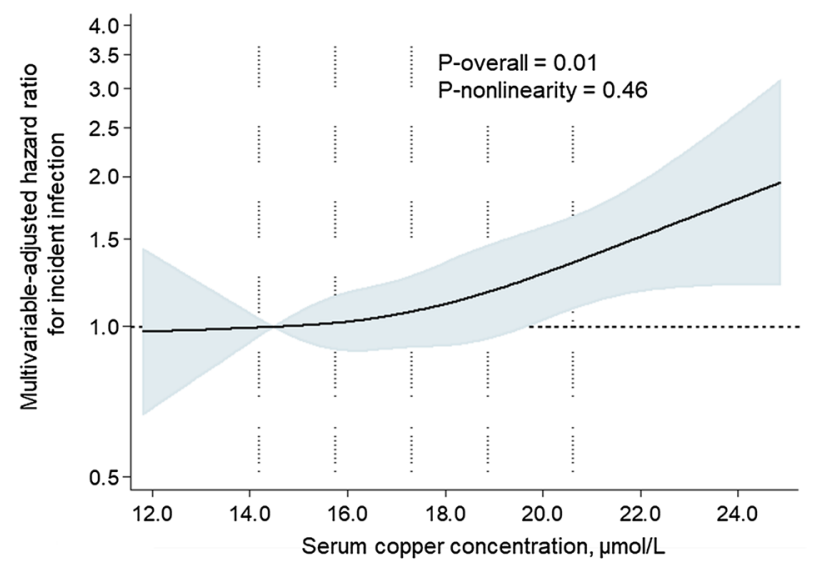

income (euros/year); intake of alcohol (g/week); leisure-time physical activity (kcal/day); and body mass index. The solid line represents the central risk estimate and the shaded area the $95 \%$ confidence interval. The dotted vertical lines correspond to 10th, 25th, 50th, 75th and 90th percentile of the serum copper-to-zinc-ratio or serum copper or zinc concentrations

associated with ageing, such as insufficient dietary Zn intake (e.g. problems of mastication leading to avoidance of $\mathrm{Zn}$ rich foods like red meat), reduced intestinal absorption or increased losses (diarrhea, diuretics) [18]. However, in our study there were no major differences in dietary intakes across quartiles of serum $\mathrm{Cu} / \mathrm{Zn}$-ratio, including $\mathrm{Zn}$ intake (Table 1), suggesting that poor nutritional status is not a likely explanation for our findings. Neither did adjustment for serum albumin as a possible marker for poor nutritional status have any impact on the risk of an incident infection. Also a mild $\mathrm{Zn}$ deficiency has an adverse influence on the immune system. Similar alterations in immune system seen in Zn deficiency and immunosenescence suggest that these might be related phenomena $[5,18]$. Additionally, a chronic exposure to cadmium can lead to a reduced renal reabsorption of $\mathrm{Zn}$ and result in decreased serum $\mathrm{Zn}$ concentration and increased $\mathrm{Cu} / \mathrm{Zn}$-ratio notably in smokers [19]. However, in our analyses $\mathrm{Zn}$ concentration was not associated 
with higher risk of an infection among the smokers, either. In this study we found an inverse association between serum $\mathrm{Zn}$ concentrations and risk of an infection with the shorter, 10-year follow-up, although without evidence for dose-response. This might be due to the attenuation of the relation during the longer follow-up time. Another potential explanation could be the small proportion of subjects (1.7\%), which had serum $\mathrm{Zn}$ concentration lower than 10.7 $\mu \mathrm{mol} / \mathrm{L}$ defined as $\mathrm{Zn}$ deficiency [40] and that higher $\mathrm{Zn}$ concentrations seem not to lower the risk of incident infections. The amount of $\mathrm{Zn}$ deficient subjects is less than the proportions reported in other studies varying from 3 to $4.8 \%$ in free-living elderly populations in Europe [40]. In the current work the mean serum $\mathrm{Zn}$ concentration $(14.4 \mu \mathrm{mol} / \mathrm{L})$ is in the same range as $\mathrm{Zn}$ values for men reported in other studies, such as in the ZENITH study [40], NHANES II Study (1976-1980) [43], and AREDS study [44]. There is no clear explanation for our finding that higher serum $\mathrm{Zn}$ concentration was associated with a lower risk among men with higher BMI, but because of the many interaction analyses, this could also be a chance finding.

The strengths of the current study are the long follow-up with a large number and detailed information of incident infections, population-based recruitment, and extensive examinations for potential confounders. The potential weakness is the single measurement of serum $\mathrm{Cu}$ and $\mathrm{Zn}$ concentrations at baseline, which may attenuate the associations during a long follow-up. This is supported by the stronger associations in the analyses with a shorter follow-up. As the study population included only middle-aged and older men from Eastern Finland, generalization to other populations should be done with caution. This includes potential gender-specific differences. In the present study the most common infection was pneumonia. It has been observed that the incidence of pneumonia in Europe is higher in men than in women [45]. In general, urinary tract infections (UTI) are the most common infections of the elderly [46]. Taking into account that the prevalence ratio of UTI between older women and men is 2:1 [47], it is conceivable that the incidence of UTI would be higher if women were included in the study population. Furthermore, it has been shown that gender differences exist in metal blood concentrations: $\mathrm{Cu}$ concentration is significantly higher in elderly women, while $\mathrm{Zn}$ concentration is higher in elderly men [48].

In conclusion, our data suggest that a higher serum $\mathrm{Cu} /$ $\mathrm{Zn}$-ratio is associated with increased risk of incident infection in middle-aged and older men. However, because serum $\mathrm{Cu}$ concentration had a stronger association with increased risk, this suggests that serum $\mathrm{Cu}$ concentration alone could be a better marker for future risk of an infection. Further research in other study populations is required to verify the results.
Acknowledgements Open access funding provided by University of Eastern Finland (UEF) including Kuopio University Hospital.

Author contributions T-PT, JTS and JKV: conceived and designed the study. JTL and JKV: analysed the dataset. JTL: wrote the first draft of the manuscript. JTL, T-PT, JTS and JKV: interpreted the results, revised the draft paper, and read and approved the final manuscript.

Funding The KIHD project was funded for the most part by research Grants to Jukka T Salonen and George A Kaplan from the National Institutes of Health and the Academy of Finland. The present contribution did not receive any special funding.

\section{Compliance with ethical standards}

Conflicts of interest The authors declare that they have no conflict of interest.

Ethical approval The KIHD study complies with the Declaration of Helsinki and has an approval from the Research Ethics Committee of the University of Kuopio.

Informed consent All subjects gave written informed consent.

Open Access This article is licensed under a Creative Commons Attribution 4.0 International License, which permits use, sharing, adaptation, distribution and reproduction in any medium or format, as long as you give appropriate credit to the original author(s) and the source, provide a link to the Creative Commons licence, and indicate if changes were made. The images or other third party material in this article are included in the article's Creative Commons licence, unless indicated otherwise in a credit line to the material. If material is not included in the article's Creative Commons licence and your intended use is not permitted by statutory regulation or exceeds the permitted use, you will need to obtain permission directly from the copyright holder. To view a copy of this licence, visit http://creativecommons.org/licenses/by/4.0/.

\section{References}

1. WHO. Ageing and health. 2018. https://www.who.int/en/newsroom/fact-sheets/detail/ageing-and-health.

2. Weiskopf D, Weinberger B, Grubeck-Loebenstein B. The aging of the immune system. Transol Int. 2009;22:1041-50.

3. Mouton CP, Bazaldua OV, Pierce B, Espino DV. Common infections in older adults. Am Fam Physician. 2001;63:257-68.

4. Liang SY, Mackowiak PA. Infections in the elderly. Clin Geriatr Med. 2007;23:441-56.

5. Haase H, Rink L. The immune system and the impact of zinc during aging. Immun Ageing. 2009;6:9. https://doi. org/10.1186/1742-4933-6-9.

6. Prasad AS. Impact of the discovery of human zinc deficiency on health. J Am Coll Nutr. 2009;28:257-65.

7. Stafford SL, Bokil NJ, Achard MES, et al. Metal ions in macrophage antimicrobial pathways: emerging roles for zinc and copper. Biosci Rep. 2013;33:e0049. https://doi.org/10.1042/bsr20 130014.

8. López de Romaña D, Olivares M, Uauy R, Araya M. Risks and benefits of copper in light of new insights of copper homeostasis. J Trace Elem Med Biol. 2011;25:3-13. 
9. Malavolta M, Piacenza F, Basso A, Giacconi R, Costarelli L, Mecchegiani E. Serum copper to zinc ratio: relationship with aging and health status. Mech Ageing Dev. 2015;151:93-100.

10. Giacconi R, Costarelli L, Piacenza F, et al. Main biomarkers associated with age-related plasma zinc decrease and copper/ zinc ratio in healthy elderly from ZincAge study. Eur J Nutr. 2017;56:2457-66.

11. Leone N, Courbon D, Ducimetiere P, Zureik M. Zinc, copper, and magnesium and risks for all-cause, cancer, and cardiovascular mortality. Epidemiology. 2006;17:308-14.

12. Reunanen A, Knekt P, Marniemi J, Mäki J, Maatela J, Aromaa A. Serum calcium, magnesium, copper and zinc and risk of cardiovascular death. Eur J Clin Nutr. 1996;50:431-7.

13. Mazdak H, Yazdekhasti F, Movahedian A, Mirkheshti N, Shafieian M. The comparative study of serum iron, copper, and zinc levels between bladder cancer patients and a control group. Int Urol Nephrol. 2010;42:89-93.

14. Dìez M, Cerdàn FJ, Arroyo M, Balibrea JL. Use of copper/zinc ratio in the diagnosis of lung cancer. Cancer. 1989;63:726-30.

15. Malavolta M, Giacconi R, Piacenza F, et al. Plasma copper/zinc ratio: an inflammatory/nutritional biomarker as predictor of all-cause mortality in elderly population. Biogerontology. 2010;11:309-19.

16. Belbraouet $\mathrm{S}$, Biaudet $\mathrm{H}$, Tébi A, Nearkasen $\mathrm{C}$, Gray-Donald $\mathrm{K}$, Debry G. Serum zinc and copper status in hospitalized vs. healthy elderly subjects. J Am Coll Nutr. 2007;26:650-4.

17. Baudry J, Kopp JF, Boeing H, Kipp AP, Schwerdtle T, Schulze MB. Changes of trace element status during ageing: results of the EPIC-Potsdam cohort study. Eur J Nutr. 2019. https://doi. org/10.1007/s00394-019-02143-w.

18. Mocchegiani E, Romeo J, Malavolta M, et al. Zinc: dietary intake and impact of supplementation on immune function in elderly. AGE. 2013;35:839-60.

19. Satarug S, Nishijo M, Ujjin P, Moore MR. Chronic exposure to low-level cadmium induced zinc-copper dysregulation. J Trace Elem Med Biol. 2018;46:32-8. https://doi.org/10.1016/j.jtemb .2017.11.008.

20. Salonen JT. Is there a continuing need for longitudinal epidemiologic research? The Kuopio ischaemic heart disease risk factor study. Ann Clin Res. 1988;20:46-50.

21. Salonen JT, Nyyssönen K, Korpela H, Tuomilehto J, Seppänen $\mathrm{R}$, Salonen R. High stored iron levels associated with excess risk of myocardial infarction in eastern Finnish men. Circulation. 1992;86:803-11.

22. Lakka TA, Venäläinen JM, Rauramaa R, Salonen R, Tuomilehto J, Salonen JT. Relation of leisure-time physical activity and cardiorespiratory fitness to the risk of acute myocardial infarction. N Engl J Med. 1994;330:1549-54.

23. Virtanen JK, Mursu J, Tuomainen TP, Voutilainen S. Dietary fatty acids and risk of coronary heart disease in men: the Kuopio ischemic heart disease risk factor study. Arterioscler Thromb Vase Biol. 2014;34:2679-87.

24. Salonen JT, Seppanen K, Kantola M, Suntioinen S, Korpela H. Interactions of serum copper, selenium, and low density lipoprotein cholesterol in atherogenesis. BMJ. 1991;302:756-60.

25. Osredkar J, Sustar N. Copper and zinc, biological role and significance of copper/zinc imbalance. J Clin Toxicol. 2011;S3:001. https://doi.org/10.4172/2161-0495.S3-001.

26. Kassu A, Yabutani T, Mahmud ZH, et al. Alterations in serum levels of trace elements in tuberculosis and HIV infections. Eur J Clin Nutr. 2006;60:580-6.

27. Asemota EA, Okafor IM, Okoroiwu HU, et al. CD4 T-cell count and some hematological parameters of HIV-infected subjects in Southern Nigeria. Integr Med Res. 2018;7:53-60.

28. Van Weyenbergh J, Santana G, D’Oliveira A Jr, et al. Zinc/copper imbalance reflects immune dysfunction in human leishmaniasis: an ex vivo and in vitro study. BMC Infect Dis. 2004;4:50. https:// doi.org/10.1186/1471-23334-4-50.
29. Lai H, Lai S, Shor-Posner G, Ma F, Trapido E, Baum MK. Plasma zinc, copper, copper: zinc ratio and survival in a cohort of HIV1-infected homosexual men. J Acquir Immune Defic Syndr. 2001;27:56-62.

30. High KP. Infection as a cause of age-related morbidity and mortality. Ageing Res Rev. 2004;3:1-14.

31. Boe DM, Boule LA, Kovacs EJ. Innate immune responses in ageing lung. Clin Exp Immunol. 2017;187:16-25.

32. Cuevas LE, Koyanagi A. Zinc and infection: a review. Ann Trop Paediatr. 2005;2:149-60.

33. Crisponi G, Nurchi VM, Fanni D, Gerosa C, Nemolato S, Faa G. Copper-related diseases: from chemistry to molecular pathology. Coord Chem Rev. 2010;254:876-89.

34. Guo C-H, Wang C-L. Effects of zinc supplementation on plasma copper/zinc ratios, oxidative stress, and immunological status in hemodialysis patients. Int J Med Sci. 2013;10:79-89.

35. Mocchegiani E, Malavolta $\mathrm{M}$, Lattanzio F, et al. $\mathrm{Cu}$ and $\mathrm{Zn}$ ratio, physical function, disability, and mortality risk in older elderly (ilSIRENTE study). Age (Dordr.). 2012;34:539-52.

36. Kouremenou-Dona E, Dona A, Papoutsis J, Spiliopoulou C. Copper and zinc concentrations in serum of healthy Greek adults. Sci Total Environ. 2006;359:76-81.

37. Uriu-Adams JY, Keen CL. Copper, oxidative stress, and human health. Mol Asp Med. 2005;26:268-98.

38. Besold AN, Culbertson EM, Culotta VC. The Yin and Yang of copper during infection. J Biol Inorg Chem. 2016;21:137-44.

39. Liuzzi JP, Lichten LA, Rivera S, et al. Interleukin-6 regulates the zinc transporter Zip14 in liver and contributes to the hypozincemia of the acute-phase response. Proc Natl Acad Sci U S A. 2005;102:6843-8.

40. Andriollo-Sanchez M, Hininger-Favier I, Meunier N, et al. Zinc intake and status in middle-aged and older European subjects: the ZENITH study. Eur J Clin Nutr. 2005;59(Suppl 2):S37-41.

41. Hood MI, Skaar EP. Nutritional immunity: transition metals at the pathogen-host interface. Nat Rev Microbiol. 2012;10:525-37.

42. Gammoh NZ, Rink L. Zinc in infection and inflammation. Nutrients. 2017;9:624. https://doi.org/10.3390/nu9060624.

43. Hotz C, Peerson JM, Brown KH. Suggested lower cutoffs of serum zinc concentrations for assessing zinc status: reanalysis of the second national health and nutrition examination survey data (1979-1980). Am J Clin Nutr. 2003;78:756-64.

44. Age-Related Eye Disease Study Research Group. The effect of five-year zinc supplementation on serum zinc, serum cholesterol and hematocrit in persons randomly assigned to treatment group in the age-related eye disease study: AREDS Report No. 7. J Nutr. 2002;132:697-702.

45. Welte T, Torres A, Nathwani D. Clinical and economic burden of community-acquired pneumonia among adults in Europe. Thorax. 2012;67:71-9.

46. Gavazzi G, Krause KH. Ageing and infection. Lancet Infect Dis. 2002;2:659-66. https://doi.org/10.1016/s1473-3099(02)00437-1.

47. Dorner TE, Schwarz F, Kranz A, Freidl W, Rieder A, Gisinger C. Body mass index and the risk of infections in institutionalised geriatric patients. Br J Nutr. 2010;103:1830-5. https://doi. org/10.1017/S0007114510000152.

48. Olsén L, Lind PM, Lind L. Gender differences for associations between circulating levels of metals and coronary risk in the elderly. Int J Hyg Environ Health. 2012;215:411-7. https://doi. org/10.1016/j.ijheh.2011.11.004.

Publisher's Note Springer Nature remains neutral with regard to jurisdictional claims in published maps and institutional affiliations. 